Original Research Paper

\title{
Production, Extraction and Characterization of Lipases from the Antarctic Yeast Guehomyces pullulans
}

\author{
Luis Lascano Demera, Patricia Portero Barahona and Enrique Javier Carvajal Barriga \\ Neotropical Center for Biomass Research, The Catholic University Yeast Collection in Quito (CLQCA), \\ School of Biological Sciences, Pontificia Universidad Católica del Ecuador, Ecuador
}

\author{
Article history \\ Received: 18-02-2019 \\ Revised: 15-03-2019 \\ Accepted: 11-04-2019 \\ Corresponding Author: \\ Javier Carvajal Barriga \\ Neotropical Center for Biomass \\ Research, School of Biological \\ Sciences, Pontificia \\ Universidad Católica del \\ Ecuador, Ecuador \\ Email: ejcarvajal@puce.edu.ec
}

\begin{abstract}
The production of extracellular lipases from the Antarctic yeast Guehomyces pullulans is induced using an olive oil medium as an inductor substrate and a first characterization of its enzyme, using the protein extract obtained from the medium, is described. For this, the effect of $\mathrm{pH}$ and temperature on the lipase activity are evaluated and the enzyme kinetic for the lipase is determined. Lipase production was $0.27 \mathrm{U} / \mathrm{mL}$, a high value compared to lipolytic activities in non-optimized media. However, this value can be increased by optimizing the culture medium. The lipase of $G$. pullulans has maximum activity at $\mathrm{pH} 8.0$ and $40^{\circ} \mathrm{C}$ (thermal stability 40 $50^{\circ} \mathrm{C}$ ). Regarding the kinetic parameters, a $\mathrm{K}_{\mathrm{M}}=3.7 \times 10^{-4} \mathrm{M}$ was obtained, a value located in the range of industrial lipases. In addition, its kinetics presented the phenomenon of interfacial activation. The results presented in this work show the biotechnological potential of the lipase due its biochemical properties and are useful for later work directed to study other factors that affect the enzyme activity and potential biotechnological applications of the Guehomyces pullulans lipase.
\end{abstract}

Keywords: Guehomyces pullulans, Antarctic Yeast, Lipase, Extracellular Production, Induction, Characterization

\section{Introduction}

Lipases (triacylglycerol acylhydrolase, EC 3.1.1.3) are hydrolases which constitute the third most important category of enzymes, after carbohydrases and proteases (Kavitha, 2016). They are ubiquitous enzymes, produced by plants, animals and microorganisms. Lipases act on insoluble substrates emulsified in water and catalyze the hydrolysis (cleaving ester bonds) of triacylglycerides composed of long-chain fatty acid (more than ten carbon atoms). Lipases differ from esterases because the latter act on water-soluble substrates, such as simple esters with short-chain fatty acids (less than six carbon atoms) (Bussamara et al., 2010; Lux et al., 2007; Sharma et al., 2001). In addition to the hydrolytic activity on triacylglycerides, lipases catalyze two groups of chemical reactions in non-aqueous media: Esterification and transesterification (Damaso et al., 2013; Hasan et al., 2009).

Currently, lipases are mainly obtained from a wide range of bacteria, fungi and yeasts (Thakur, 2012; Treichel et al., 2010). Yeasts are the main source of biotechnological products in the world, exceeding in production other industrial microorganisms. Enzymes such as lipases are part of the multiple products with biotechnological and industrial potential (Kurtzman et al., 2011). Lipases have gained attention due to the amount of chemo-, regio- and stereoselective transformations they catalyze, thanks to their characteristics such as substrate specificity, regional specificity and chiral selectivity (stereoselective). For this reason, new biotechnological applications have been established using lipases in the synthesis of biopolymers and biodiesel, enantiopure pharmaceuticals, agrochemicals, biosensors, additives for detergents and food processing (Sharma et al., 2001; Shimada et al., 2002; Tan et al., 2010). Among the commercially important lipaseproducing yeasts or those with potential biotechnological applications are: Candida sp., which includes Candida rugosa and Candida antarctica, also Yarrowia lipolytica and others species of Pichia sp., Rhodotorula sp. and Trichosporon sp. Due to their high performance and enzymatic properties, the genes encoding lipases from Candida sp., Trichosporon sp. and $Y$. lipolytica have been cloned and overexpressed (Sharma et al., 2011; Thakur, 2012; Treichel et al., 2010; Vakhlu and Kour, 2006). 
Although most studies on yeast lipases refer to the species mentioned above, there are some lipase-producing yeasts that have potential for biotechnological innovation (Bussamara et al., 2010; Thakur, 2012) In addition, about $2 \%$ of the microorganisms have been proven as enzyme sources (Hasan et al., 2006). This figure allows us to understand the extensive research that can be carried out to discover and characterize new enzymes. This is the case of the basidiomycete yeast Guehomyces pullulans used in the study, which has been specially studied for the production of the enzyme $\beta$ galactosidase, an enzyme with hydrolytic activity on lactose (Kurtzman et al., 2011). The production of lipases by $G$. pullulans was reported in a bioprospecting carried out by Martorell et al. (2017). Consequently, in this research is performed a lipase production from $G$. pullulans and is carried out an enzyme characterization where the effect of temperature, $\mathrm{pH}$ and enzymatic kinetics are analyzed. This provide a useful approach aimed at obtaining a new biocatalyst with the desired enzymatic capacity.

\section{Materials and Methods}

\section{Induction to the Secretion of the Lipase}

\section{Microorganism}

The yeast Guehomyces pullulans (strain CLQCAANT-073) belongs to the Quito-Catolica Yeast Collection of the Pontificia Universidad Catolica del Ecuador (CLQCA). It was selected on the basis of a lipase/esterase screening of 49 independent yeast isolates, including 7 Antarctic species, from the CLQCA.

\section{Culture Conditions}

Guehomyces pullulans (CLQCA-ANT-073) was incubated on YM agar medium for 5 days at $25^{\circ} \mathrm{C}$. For lipase production, yeast biomass was inoculated in a liquid culture medium composed of: $0.2 \%$ glucose, $0.5 \%$ peptone, $0.01 \% \mathrm{MgSO}_{4}, 0.1 \% \mathrm{~K}_{2} \mathrm{HPO}_{4}, 5 \%$ gum Arabic and $2 \%$ olive oil as inducer (Bussamara et al., 2010; Dhiman and Chapadgaonkar, 2013). The pH was adjusted to 5.0 and the culture medium was sterilized at $121^{\circ} \mathrm{C}$ for $15 \mathrm{~min}$. The yeast culture $(50 \mathrm{~mL})$ was incubated by shaking at $200 \mathrm{RPM}$ for 40 days at $20^{\circ} \mathrm{C}$.

\section{Protein Extraction and Purification}

The inducer medium was centrifuged at 14,000 RPM for $10 \mathrm{~min}$ at $4{ }^{\circ} \mathrm{C}$. Proteins in the supernatant were precipitated by salting-out with $75 \%$ ammonium sulfate for $5 \mathrm{~h}$ at $4^{\circ} \mathrm{C}$. A protein pellet was obtained by centrifugation and resuspended in $50 \mathrm{mM}$ phosphate buffer, $\mathrm{pH}$ 7.0. Aliquots were stored at $-30^{\circ} \mathrm{C}$ for later use (Bae et al., 2014; Bussamara et al., 2010; Joseph et al., 2012; Kumar et al., 2005). Protein concentration was determined by spectrophotometry using the Bradford method, with BSA as a standard.

\section{Detection of Lipase Activity}

The chromogenic medium used for lipase detection was: $1 \%$ olive oil, $10 \mathrm{mM} \mathrm{CaCl}_{2}, 2 \%$ agar and $0.01 \%$ phenol red as an indicator of the $\mathrm{pH}$ shift. Medium $\mathrm{pH}$ was adjusted with $0.1 \mathrm{M} \mathrm{NaOH}$ (to fuchsia-red coloration), sterilized at $121^{\circ} \mathrm{C}$ for $15 \mathrm{~min}$ and dispensed in Petri dishes (Nath and Hindumathy, 2012; Singh et al., 2006).

Six wells were made in the middle of the medium. In each well, $100 \mu \mathrm{L}$ of protein extract was added at different concentrations: $0.4,0.04$ and $0.004 \mathrm{mg} / \mathrm{mL}$ diluted in phosphate buffer $\mathrm{pH} 7$ and $0.04 \mathrm{mg} / \mathrm{mL}$ diluted in water. In addition, water and phosphate buffer were used as controls. The plate was incubated at $30^{\circ} \mathrm{C}$ for $2.5 \mathrm{~h}$.

\section{Characterization of the Lipase}

\section{Quantitative Determination of Lipase Activity}

Lipase enzymatic activity was determined by spectrophotometry using $p$-Nitrophenyl Palmitate ( $p$ NPP) as a substrate. The activity was quantified by measuring (at $410 \mathrm{~nm}$ ) the increase of $p$-nitrophenol $(p \mathrm{NP})$ released by the protein extract incubated for $30 \mathrm{~min}$ at $37^{\circ} \mathrm{C}$ and pH 7.0, against a blank without the enzyme source. To initiate the reaction, $0.1 \mathrm{~mL}$ of the lipase solution (protein extract) was added into $0.9 \mathrm{~mL}$ of substrate/buffer solution containing $3 \mathrm{mg}$ of $p \mathrm{NPP}$ dissolved in $1 \mathrm{~mL}$ of isopropanol and $9 \mathrm{~mL}$ of the following solution: 4.4 $\mathrm{mg} / \mathrm{mL}$ Triton $\mathrm{X}-100$ and $1.1 \mathrm{mg} / \mathrm{mL}$ gum arabic in 50 $\mathrm{mM}$ phosphate buffer $\mathrm{pH}$ 7.0. A progress curve was constructed and enzymatic activity (U/mL) was calculated. A Lipase Unit (U) was defined as the amount of enzyme that release $1 \mu \mathrm{mol}$ of $p \mathrm{NP}$ per minute under the experimental conditions. A calibration curve was prepared using $p \mathrm{NP}$ as standard (Bussamara et al., 2010; Damaso et al., 2013; Garcia Roman, 2005; Mercado-Malebran, 2014; Wrolstad et al., 2005).

\section{Enzymatic Kinetic Study}

Kinetic parameters were determined by studying the effect of $p$ NPP concentration $(7.9,79,400,790$ and $1600 \mu \mathrm{M})$ on the reaction rate. Enzymatic activity for each concentration was measured during $30 \mathrm{~min}$ at $37^{\circ} \mathrm{C}$ and $\mathrm{pH}$ 7.0. The experiment was carried out in triplicate. $V_{\max }$ and $K_{M}$ were calculated by fitting the curve to the Michaelis-Menten model by the Lineweaver-Burk method.

\section{Thermal Stability and $p H$ Effect}

Lipase thermal stability was estimated by incubating $0.1 \mathrm{~mL}$ of the protein extract for 1 hour at different temperatures $\left(30,40,50\right.$ and $\left.60^{\circ} \mathrm{C}\right)$ in the absence of substrate. Then, the residual activity was measured at $50^{\circ} \mathrm{C}$ and $\mathrm{pH} 7.0$ for $30 \mathrm{~min}$ using $p \mathrm{NPP}$ as substrate (Bussamara et al., 2010; Juntachai et al., 2011). Four repetitions were performed for each trial. Subsequently, 
the enzymatic activity average was calculated. For the statistical analyze, a completely randomized design ANOVA was performed for unequal samples with a Tukey post hoc test.

Optimum $\mathrm{pH}$ was determined by quantifying the enzymatic activity at different $\mathrm{pH}(6.0,7.0,8.0,9.0$ and 10.0) (Bussamara et al., 2010; Juntachai et al., 2011). Four repetitions were performed at $37^{\circ} \mathrm{C}$ for $30 \mathrm{~min}$ and the relative enzymatic activity was calculated. For the statistical analyze, a completely randomized design ANOVA was performed for unequal samples with a Tukey post hoc test.

\section{Results and Discussion}

\section{Detection of Lipase Activity}

The presence of lipases in the protein extract was determined by a chromogenic method. At the end of the incubation period, a color change from fuchsia to yellow was observed in the well of the most concentrated sample $(0.4 \mathrm{mg} / \mathrm{mL})$, forming a $1 \mathrm{~cm}$ in diameter ring (Fig. 1A). The samples diluted in phosphate buffer $(0.04$ and $0.004 \mathrm{mg} / \mathrm{mL})$ displayed a blurred and almost imperceptible halo (Fig. 1B and 1C). The dilution of the sample in water did not show ring formation (Fig. 1F). In the control samples (Fig. 1D and $1 \mathrm{E}$ ) there was no change in coloration, which rules out any interference in the reaction.

The chromogenic medium evidenced the presence of lipase activity. The fatty acids released by the enzymatic action lead to the medium acidification, which takes on a yellow coloration when the $\mathrm{pH}$ is acidic (Nath and Hindumathy, 2012). This result shows the presence of lipases in the protein extract.

The similarity of $\mathrm{B}$ and $\mathrm{C}$ rings even though there is a 10 -fold reduction in concentration, could be explained by the sensitivity of the method. While the method has been reported by Singh et al. (2006) to be highly sensitive (can detect as low as 0.5 enzyme units within $15 \mathrm{~min}$ ), the concentrations of samples $\mathrm{B}$ and $\mathrm{C}$ were below this minimum range. Consequently, a relative lack of sensitivity probably occurred leading to no difference between $\mathrm{B}$ and $\mathrm{C}$ rings. Also, at concentrations below this minimum range, the amount of fatty acids released is not enough to produce the color-change into a brilliant yellow, even when a drop in $\mathrm{pH}$ have occurred and a change to red color is observed, as in B and $\mathrm{C}$ samples (Singh et al., 2006). This also contributed to the absent of the ring in the sample diluted in water (F). However, the difference between $\mathrm{F}$ and $\mathrm{B}$, that have the same concentrations, suggests that the phosphate buffer $\mathrm{pH} 7.0$ in dilutions $\mathrm{B}$ and $\mathrm{C}$ favored the enzymatic activity, in contrast to the water-diluted sample (F), since most lipases work in an optimal $\mathrm{pH}$ range between 7.0 and 8.0 (Sharma et al., 2001).

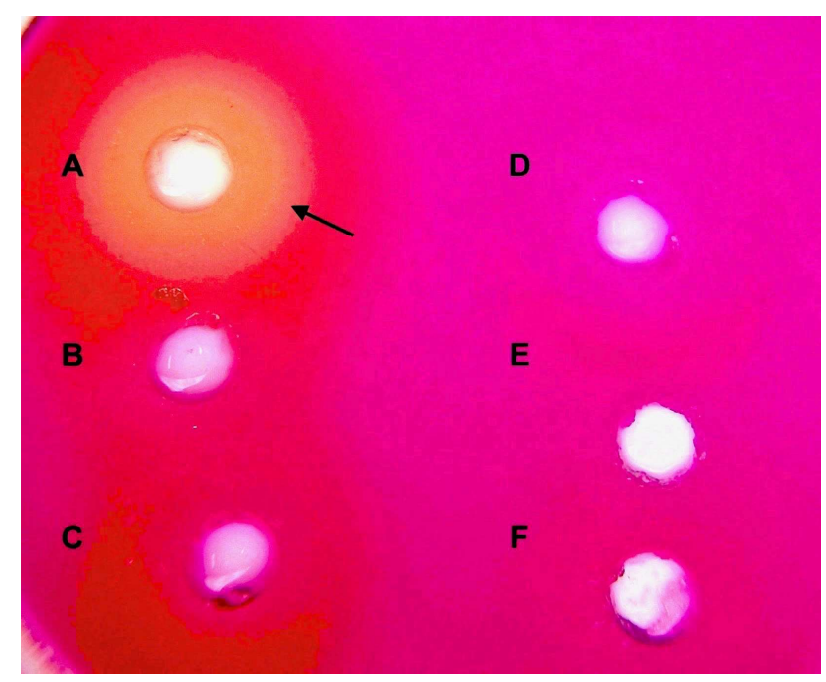

Fig. 1: Detection of lipase activity in the chromogenic medium. The medium contained phenol red as a colorimetric indicator. (A). Sample $0.4 \mathrm{mg} / \mathrm{mL}$. (B). Sample $0.04 \mathrm{mg} / \mathrm{mL}$. (C). Sample $0.004 \mathrm{mg} / \mathrm{mL}$. (D). Buffer sodium phosphate $\mathrm{pH}$ 7.0. (E). Distilled water. (F). Sample diluted in water $0.04 \mathrm{mg} / \mathrm{mL}$. The formation of a yellow ring around $\mathrm{A}$, indicates the presence of lipases in the extract

\section{Lipase Enzymatic Activity}

The lipase produced with olive oil as inducer showed an activity of $0.27 \mathrm{U} / \mathrm{mL}$. Enzyme production is a function of microbial growth, the inductor substrate used and the different ways of optimizing the medium (media composition, $\mathrm{pH}$, presence of both activators and inhibitors that affect cell growth and lipases production, agents that affect the interface, processes fermentation, etc.) (Dhiman and Chapadgaonkar, 2013; Hadeball, 1991; Jonsson and Snygg, 1974; Sharma et al., 2001).

Lipase production studies (Bussamara et al., 2010; Cardenas et al., 2001; Rapp and Backhaus, 1992; Singh and Mukhopadhyay, 2012; Thakur, 2012) distinguish between enzymatic activities in optimized and in non-optimized culture media. The lipase activity for $G$. pullulans reported here $(0.27 \mathrm{U} / \mathrm{mL})$ was from a nonoptimized medium and it is considered high when compared with enzymatic activities between 0.002-0.3 U/mL reported by Bussamara et al. (2010) for 29 yeast isolates in nonoptimized induction media. In addition, it was also higher to those reported by Rapp and Backhaus (1992) for 15 yeast isolates in non-optimized media (0.002-0.15 $\mathrm{U} / \mathrm{mL}$ ). However, in optimized culture media it is possible to significantly increase the enzymatic activity. For example, Candida rugosa, cataloged as the best lipase producer, can increase its activity from 20-40 $\mathrm{U} / \mathrm{mL}$ to $117 \mathrm{U} / \mathrm{mL}$ by several optimization processes (Tan et al., 2003), even when starting from activities between $0.1-0.7 \mathrm{U} / \mathrm{mL}$, as reported by early studies (Dalmau et al., 2000). 
Incubation time and temperature are also factors that influence lipase production (Park et al., 2013). In this study, Guehomyces pullulans (CLQCA-ANT-073) was incubated for $960 \mathrm{~h}$ at $20^{\circ} \mathrm{C}$. Incubation times reported in the literature are from 24 to $180 \mathrm{~h}$, depending on the cultivation method, microorganism and the different ways of optimizing (Singh and Mukhopadhyay, 2012). However, in the case of cold adapted yeasts, the incubation times are longer: 240,348 and $624 \mathrm{~h}$ with temperatures of $15-30^{\circ} \mathrm{C}$, showing high activities at $15^{\circ} \mathrm{C}$ and $20^{\circ} \mathrm{C}$ (Bae et al., 2014; Joseph et al., 2012; Park et al., 2013).

Guehomyces pullulans was recently reported as a lipase-producer in a bioprospection of 102 isolates from Antarctic yeasts (Martorell et al., 2017). Therefore, there is no additional information regarding the factors and conditions that control its biosynthesis and secretion. For this reason, the results reported here should be considered as complementary contribution for the optimization process in order to improve the production of lipases from Guehomyces pullulans.

\section{Kinetic Parameters}

The kinetic curve for $G$. pullulans lipase showed the phenomenon of interfacial activation (Fig. 2) as it occurs in the majority of lipases (Reis et al., 2009; Sanchez Ferrer, 1998; Sharma et al., 2001; Verger, 1997). In this interfacial kinetics, the reaction rate increases after a substrate concentration close to $400 \mu \mathrm{M}$, being this value defined as an approximation to the critical micellar concentration.

Kinetic parameters were calculated by the Lineweaver-Burk linearization. $\mathrm{V}_{\max }$ and $\mathrm{K}_{\mathrm{M}}$ were 6.7 $\mu \mathrm{mol} / \mathrm{min} / \mathrm{mL}$ and $3.68 \times 10^{-4} \mathrm{M}$, respectively. This $\mathrm{K}_{\mathrm{M}}$ was lower than the one reported for Pichia lynferdii $\mathrm{Y}$ 7723 lipase $\left(1.68 \times 10^{-3} \mathrm{M}\right)$ (Bae et al., 2014), suggesting that the affinity of the $G$. pullulans enzyme is relatively high. On the other hand, $\mathrm{K}_{\mathrm{M}}$ for Candida rugosa lipase B $\left(4.2 \times 10^{-4} \mathrm{M}\right)$ (Pereira et al., 2001) was similar to the one in G. pullulans.

$\mathrm{K}_{\mathrm{M}}$ for $G$. pullulans lipase was higher than those reported for Yarrowia lipolytica NCIM 3639 lipase $\left(2.2 \times 10^{-5} \mathrm{M}\right)$ (Sathish Yadav et al., 2011) and for $C$. rugosa lipase A $\left(3.92 \times 10^{-5} \mathrm{M}\right)$ (Gonzalez et al., 2010), suggesting that the substrate affinity of the G. pullulans enzyme is relatively lower than those. It is worth noting that substrate affinity is within the range $\left(10^{-1}-10^{-5}\right)$ of most industrial lipases (Bae et al., 2014). Consequently, this result suggests that the lipase from $G$. pullulans (CLQCA-ANT-073) would have a potential industrial use.

\section{Thermal Stability and pH Effect}

The residual activity of the G. pullulans lipase was evaluated after incubation for 1 hour over a wide range of temperatures $\left(30-60^{\circ} \mathrm{C}\right.$; Fig. 3$)$. The maximum activity was found at $40^{\circ} \mathrm{C}$. The enzyme retained $80 \%$ of its maximum activity at $50^{\circ} \mathrm{C}$. In contrast, the enzyme only retained $45 \%$ activity at 30 and $60^{\circ} \mathrm{C}$. The optimal stability temperature was defined between 40 and $50^{\circ} \mathrm{C}$ by the Tukey test. This rules out G. pullulans lipase as a coldactive enzyme, but it shows its greater thermostability compared to the cold-active lipase of Pichia lynferdii $\mathrm{Y}$ $7723\left(5-30^{\circ} \mathrm{C}\right)$ (Bae et al., 2014) and with Candida rugosa lipase $\left(35-40^{\circ} \mathrm{C}\right)$ (Vakhlu and Kour, 2006).

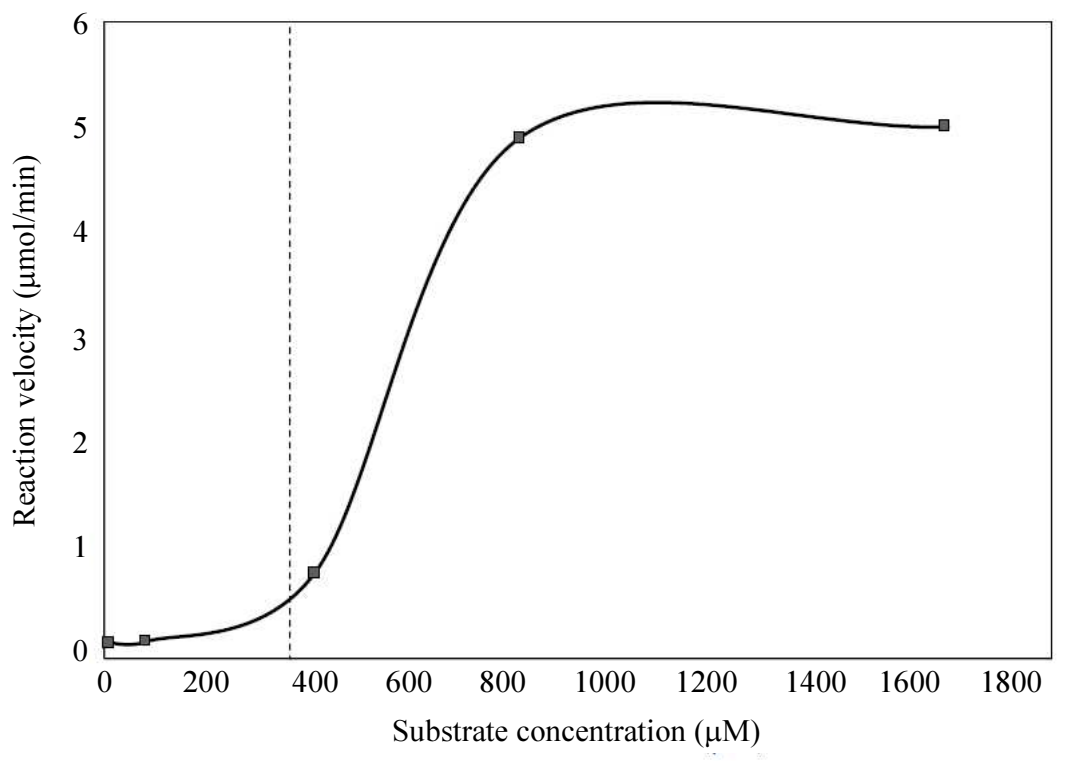

Fig. 2: Interfacial enzymatic kinetics of the lipase from Guehomyces pullulans. Five concentrations of substrate were used for each activity assay. The dotted line represents the moment of interfacial activation at a concentration close to $400 \mu \mathrm{M}$. This point indicates the critical micelle concentration 


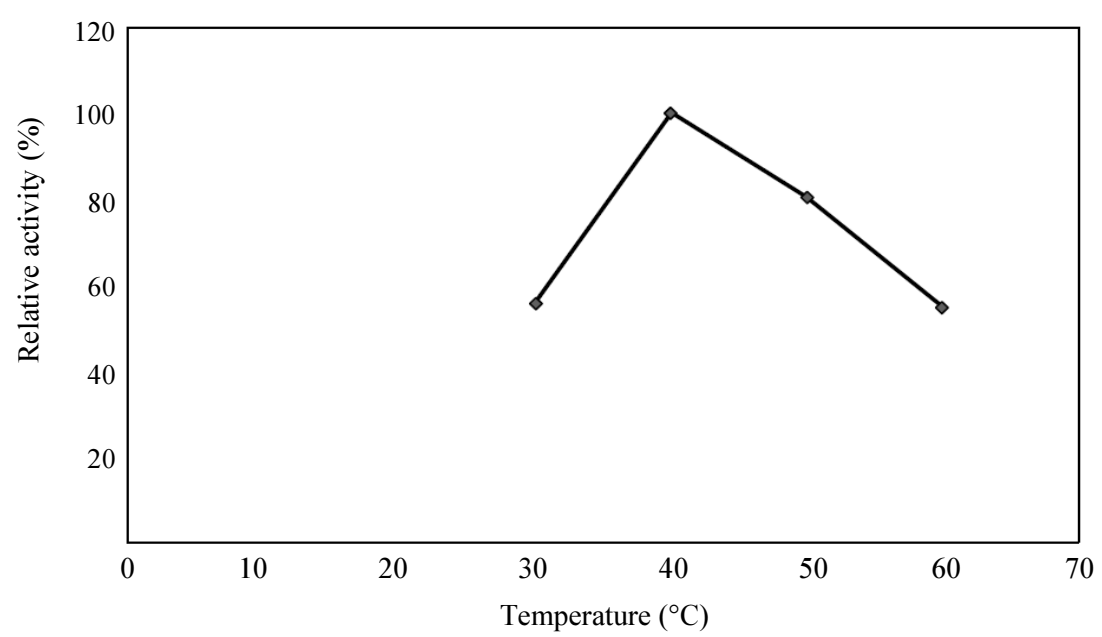

Fig. 3: Effect of temperature on the thermal stability of the lipase from Guehomyces pullulans. Enzyme activity assays were performed after incubating the lipase at the indicated temperatures for 1 hour. The optimum temperature is in the range of $40-50^{\circ} \mathrm{C}$

Commonly, cold-active lipases exhibit high activity at low temperatures $\left(0-20^{\circ} \mathrm{C}\right)$, but reduced thermostability (Bae et al., 2014; Kavitha, 2016). On the other hand, highly thermostable lipases show optimal temperature values of $50-75^{\circ} \mathrm{C}$ (Gonzalez et al., 2010; Sharma et al., 2011). Consequently, the optimum temperature of the lipase of $G$. pullulans $\left(40-50^{\circ} \mathrm{C}\right)$ is highly favorable, since being thermostable up to $50^{\circ} \mathrm{C}$ requires relatively less activation energy than the highly thermostable ones and, in turn, it is sufficiently high to promote lower risks of microbial contamination in industrial processes (Hasan et al., 2006; Pereira et al., 2001).

The development of this thermostable lipase (40$50^{\circ} \mathrm{C}$ ) in G. pullulans, even though it is a cold-adapted yeast, could be explained by the kind of cold-adapted isolate we used in our work. Martorell et al. (2017) have determined that $G$. pullulans could be psychrophilic or psychrotolerant. These two forms of microorganisms colonize cold habitats such as Antarctica permanently or temporarily. However, only psychrophilic microorganisms, which are widely prevalent in permanently cold habitats, are still capable of growing at $0^{\circ} \mathrm{C}$ (or below) due to their unique physiological adaptations, such as the synthesis of cold active enzymes (flexible but not thermostable enzymes). Also, we could consider them "obligate psychrophiles" as they failing to grow above $20^{\circ} \mathrm{C}$. In contrast, the psychrotolerant grow at approximately $0^{\circ} \mathrm{C}$, but have an optimal growth above $20^{\circ} \mathrm{C}$ and are predominant in environments with periodic low temperatures. That means that psychrotolerant organisms evolved their physiology to tolerate cold, but they are not as specialized as psychrophiles, so the production of cold-active enzymes does not occur. Therefore, their enzymes can have more thermostability but less efficiency in low temperatures than the cold- active enzymes (Baeza et al., 2017; Kavitha, 2016; Martorell et al., 2017; Shivaji and Prasad, 2009).

The production of the G. pullulans thermostable lipase suggests that this enzyme comes from a psychrotolerant isolate, capable to synthesize a thermostable lipase. Another example is the lipase CAL-A of the Antarctic yeast Candida antarctica, that is considered the most thermostable lipase known (Kirk and Christensen, 2002; Shivaji and Prasad, 2009). It also can be possible since, although the Antarctic climate is mainly cold, the presence of several geothermal sites, including thermal springs, fumaroles, hot soils and hydrothermal vents, provides ideal environments for the development of thermophilic and hyperthermophilic microorganisms (Flores et al., 2018).

To determine the optimum $\mathrm{pH}$, the activity of the lipase from $G$. pullulans was assayed in a $\mathrm{pH}$ range (6.010.0; Fig. 4). The results showed a significant difference in the enzymatic activity, which indicates the dependence on $\mathrm{pH}$. The maximum activity was recorded at $\mathrm{pH} 8.0$. At neutral $\mathrm{pH}$ the enzyme still retained $83 \%$ of its maximum activity. On the other hand, at pH 6.0 and 9.0 the enzyme retained 36 and $42 \%$, respectively. The lower activity was recorded at $\mathrm{pH} 10.0$, where the enzyme only retained $10 \%$ of its activity. The optimum $\mathrm{pH}$ was defined at 8.0 using the Tukey test, which indicates that lipase activity is best at a slightly alkaline $\mathrm{pH}$.

Most lipases reported in the literature have optimal activity at neutral or slightly basic $\mathrm{pH}$ values, as is the case of C. rugosa lipases, whose optimal values of 7.8 resembles the recorded in this study for G. pullulans lipase (Bussamara et al., 2010; Sharma et al., 2001; Vakhlu and Kour, 2006). It is known that a change in $\mathrm{pH}$ can lead to ionizable amino acids to undergo a change in their charges, followed by possible conformational changes in the enzyme active site (Bae et al., 2014; Berg et al., 2014). 


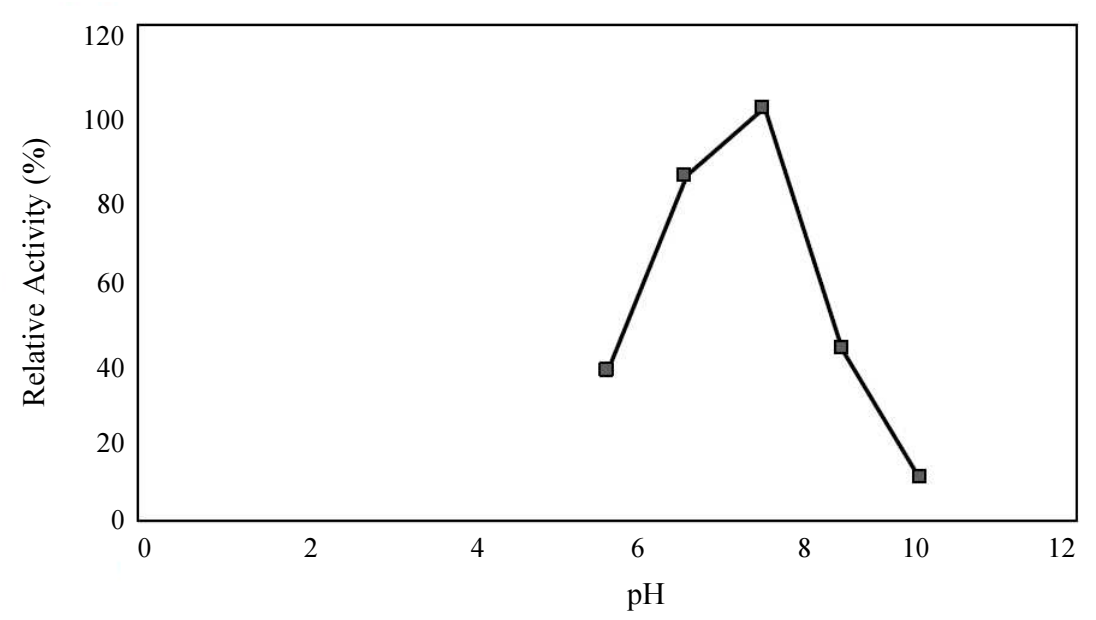

Fig. 4: Effect of $\mathrm{pH}$ on the enzymatic activity of the lipase of Guehomyces pullulans. The activity tests were carried out at the indicated $\mathrm{pH}$ and a temperature of $37^{\circ} \mathrm{C}$. The optimum $\mathrm{pH}$ value was 8.0

It has been proposed that, in lipases, this tendency to alkaline $\mathrm{pH}$ could be due to an electrostatic repulsion between the negatively charged active site and the ionized fatty acids at alkaline $\mathrm{pH}$, which leads to a rapid release of the reaction products of the interface (Reis et al., 2009).

\section{Conclusion}

In this study, the lipase production from Guehomyces pullulans (CLQCA-ANT-073) in an olive oil inducer medium was high for a non-optimized medium. This shows that olive oil is a good inducer, which, however, can be replaced by another lipid substrate for lipases that could increase enzyme production in a media optimization process in future studies in order to have more enzyme for biotechnological proposes.

The lipase showed a significant dependence on $\mathrm{pH}$ and temperature to achieve maximum enzymatic activity, acting better in slightly alkaline conditions and at moderate temperatures. Regarding the kinetic parameters of the lipase, these are comparable to those of the most important reported lipases from other yeasts and show the enzyme potential for possible industrial uses.

The results present in this study constitute a first characterization of the lipase of Guehomyces pullulans, recently cataloged as a lipase-producer and could be useful for later work directed to study other factors that affect the enzyme activity, including inhibitors and activators and potential biotechnological applications.

\section{Acknowledgement}

The authors are grateful to the Instituto Antártico Ecuatoriano (INAE); the Pontifica Universidad Catolica del Ecuador and the Project FRACMAS for providing financial support to carried out this research.

\section{Author's Contributions}

Luis Lascano Demera: Conducted literature research, carried out the whole laboratory work, designed and performed the experiments, wrote the manuscript and performed the data analysis.

Patricia Portero Barahona: Provided criteria for the design of microbiology experiments, kinetics, and revised the manuscript.

Enrique Javier Carvajal Barriga: Was the scientific director of the project. He established the research objectives; supported the design of experiments, data analysis, manuscript writing and collected the yeast strains at the Ecuadorian Antarctic Scientific Station by February 2012.

\section{Ethics}

The authors declare no ethical issues for the publication of this research work.

\section{References}

Bae, J.H., M.H. Kwon, I.H. Kim, C.T. Hou and H.R. Kim, 2014. Purification and characterization of a cold-active lipase from Pichia lynferdii Y-7723: pH-dependant activity deviation. Biotechnol. Bioprocess Eng., 19: 851-857. DOI: 10.1007/s12257-014-0300-5

Baeza, M., J. Alcaino, V. Cifuentes, B. Turchetti and P. Buzzini, 2017. Cold-Active Enzymes from ColdAdapted Yeasts. In: Biotechnology of Yeasts and Filamentous Fungi, Sibirny, A. (Ed.), Springer, Cham, pp: 297-324.

Berg, J.M., J.L. Tymoczko and L. Stryer, 2014. Biochemistry a Short Course. 2nd Edn., Editorial Reverte, Barcelona, pp: 761. 
Bussamara, R., A.M. Fuentefria, E.S. de Oliveira, L. Broetto and M. Simcikova et al., 2010. Isolation of a lipase-secreting yeast for enzyme production in a pilot-plant scale batch fermentation. Bioresour. Technol., 101: 268-275.

DOI: $10.1016 /$ j.biortech.2008.10.063

Cardenas, F., E. Alvarez, M.S. De Castro-Alvarez, J.M. Sanchez-Montero and M. Valmaseda et al., 2001. Screening and catalytic activity in organic synthesis of novel fungal and yeast lipases. J. Mol. Catal. - B Enzym., 14: 111-123.

DOI: $10.1016 / \mathrm{S} 1381-1177(00) 00244-7$

Dalmau, E., J. Montesinos, M. Lotti and C. Casas, 2000. Effect of different carbon sources on lipase production by Candida rugosa. Enzyme Microb. Technol., 26: 657-663.

DOI: 10.1016/S0141-0229(00)00156-3

Damaso, M.C.T., T.F.C. Salum, S.D. Terzi and S. Couri, 2013. Assay Methods for Lipase Activity. In: Methods to Determine Enzymatic Activity, Vermelho, A.B. and S. Couri (Eds.), Bentham, Rio de Janeiro, pp: 161-194.

Dhiman, S. and S.S. Chapadgaonkar, 2013. Optimization of lipase production medium for a bacterial isolate. Int. J. ChemTech. Res., 5: 2837-2843.

Flores, P.A.M., D.N. Correa-Llanten and J.M. Blamey, 2018. A thermophilic microorganism from Deception Island, Antarctica with a thermostable glutamate dehydrogenase activity. Biol. Res. DOI: $10.1186 / \mathrm{s} 40659-018-0206-3$

Garcia Roman, M., 2005. Hidrolisis enzimatica de trigliceridos en emulsiones $\mathrm{o} / \mathrm{w}$. Aplicacion a formulaciones detergentes. Universidad de Granada. Espana.

Gonzalez, J., J.R. Hernandez and A.D.M. Martinez, 2010. Las lipasas: Enzimas con potencial para el desarrollo de biocatalizadores inmovilizados por adsorcion interfacial. Rev. Colomb. Biotecnol., 12: 124-140.

Hadeball, W., 1991. Production of lipase by Yarrowia lipolytica, I. Lipases from yeasts. Eng. Life Sci., 11: 159-167. DOI: 10.1002/abio.370110217

Hasan, F., A.A. Shah and A. Hameed, 2006. Industrial applications of microbial lipases. Enzyme Microb. Technol., 39: 235-251.

DOI: 10.1016/j.enzmictec.2005.10.016

Hasan, F., A.A. Shah and A. Hameed, 2009. Methods for detection and characterization of lipases: A comprehensive review. Biotechnol. Adv., 27: 782-798. DOI: 10.1016/j.biotechadv.2009.06.001

Jonsson, U. and B.G. Snygg, 1974. Lipase production and activity as a function of incubation time, $\mathrm{pH}$ and Temperature of Four Lipolytic Micro-organisms. J. Appl. Microbiol., 37: 671-681.

DOI: $10.1111 /$ j.1365-2672.1974.tb00482.x
Joseph, B., N. Shrivastava and P.W. Ramteke, 2012. Extracellular cold-active lipase of Microbacterium luteolum isolated from Gangotri glacier, western Himalaya: Isolation, partial purification and characterization. J. Genet. Eng. Biotechnol., 10: 137-144. DOI: 10.1016/j.jgeb.2012.02.001

Juntachai, W., T. Oura and S. Kajiwara, 2011. Purification and characterization of a secretory lipolytic enzyme, MgLIP2, from Malassezia globosa. Microbiology, 157: 3492-3499. DOI: 10.1099/mic.0.054528-0

Kavitha, M., 2016. Cold active lipases - an update. Front. Life Sci., 9: 226-238.

DOI: $10.1080 / 21553769.2016 .1209134$

Kirk, O. and M.W. Christensen, 2002. Lipases from Candida antarctica: Unique biocatalysts from a unique origin. Org. Process Res. Dev. DOI: $10.1021 /$ op0200165

Kumar, S., K. Kikon, A. Upadhyay, S.S. Kanwar and R. Gupta, 2005. Production, purification and characterization of lipase from thermophilic and alkaliphilic Bacillus coagulans BTS-3. Protein Expr. Purif., 41: 38-44. DOI: 10.1016/j.pep.2004.12.010

Kurtzman, C.P., J.W. Fell and T. Boekhout, 2011. The Yeasts: A Taxonomic Study. 5th Edn., Elsevier, Londres, pp: 2384.

Lux, L., L. Valeriano, A. Corbellini and P. Valente, 2007. Lipases produced by yeasts: Powerful biocatalysts for industrial purposes. Tecno-lógica. Santa Cruz do Sul, 11: 18-25.

Martorell, M.M., L.A.M. Ruberto, P.M. Fernandez, L.I. Castellanos de Figueroa and W.P. Mac Cormack, 2017. Bioprospection of cold-adapted yeasts with biotechnological potential from Antarctica. J. Basic Microbiol., 57: 504-516. DOI: $10.1002 /$ jobm.201700021

Mercado-Malebran, F., 2014. Modelamiento estructural y caracterizacion de una lipasa activa a bajas temperaturas mediante ingenieria de proteinas. Universidad de Chile.

Nath, M. and C.K. Hindumathy, 2012. Isolation, optimization and purification. Int. J. Latest Res. Sci. Technol., 1: 239-246.

Park, S.Y., J.Y. Kim, J.H. Bae, C.T. Hou and H.R. Kim, 2013. Optimization of culture conditions for production of a novel cold-active lipase from Pichia lynferdii NRRL Y-7723. J. Agric. Food Chem., 61: 882-886. DOI: $10.1021 /$ jf304919y

Pereira, E., H. De Castro, F. De Moraes and G. Zanin, 2001. Kinetic studies of lipase from Candida rugosa. Applied Biochem. Biotechnol., 91-93: 739-752. DOI: 10.1007/978-1-4612-0217-2_62

Rapp, P. and S. Backhaus, 1992. Formation of extracellular lipases by filamentous fungi, yeasts and bacteria. Enzyme Microb. Technol., 14: 938943. DOI: 10.1016/0141-0229(92)90059-W 
Reis, P., K. Holmberg, H. Watzke, M.E. Leser and R. Miller, 2009. Lipases at interfaces: A review. Adv. Colloid Interface Sci., 147-148: 237-250. DOI: $10.1016 /$ j.cis.2008.06.001

Sanchez Ferrer, A., 1998. Recuperacion, purificacion y caracterizacion de lipasas producidas por Candida rugosa. Aplicacion a la resolucion de compuestos quirales $y$ diseno del reactor enzimatico. Universidad Autonoma de Barcelona.

Sathish Yadav, K.N., M.G. Adsul, K.B. Bastawde, D.D. Jadhav and H.V. Thulasiram et al., 2011. Differential induction, purification and characterization of cold active lipase from Yarrowia lipolytica NCIM 3639. Bioresour. Technol., 102: 10663-10670. DOI: 10.1016/j.biortech.2011.09.013

Sharma, D., B. Sharma and A.K. Shukla, 2011. Biotechnological approach of microbial lipase: A review. Biotechnology, 10: 23-40. DOI: 10.3923/biotech.2011.23.40

Sharma, R., Y. Chisti, U. Chand and U.C. Banerjee, 2001. Production, purification, characterization and applications of lipases. Biotechnol. Adv., 19: 627662. DOI: 10.1016/S0734-9750(01)00086-6

Shimada, Y., Y. Watanabe, A. Sugihara and Y. Tominaga, 2002. Enzymatic alcoholysis for biodiesel fuel production and application of the reaction to oil processing. J. Mol. Catal. - B Enzym., 17: 133-142. DOI: 10.1016/S1381-1177(02)00020-6

Shivaji, S. and G.S. Prasad, 2009. Antarctic yeasts: Biodiversity and potential applications. In: Yeast Biotechnology: Diversity and Applications, Satyanarayana, T. and G. Kunze (Eds.), Springer, Dordrecht, pp: 3-18.

Singh, A.K. and M. Mukhopadhyay, 2012. Overview of fungal lipase: A review. Applied Biochem. Biotechnol., 166: 486-520.

DOI: $10.1007 / \mathrm{s} 12010-011-9444-3$
Singh, R., N. Gupta, V.K. Goswami and R. Gupta, 2006. A simple activity staining protocol for lipases and esterases. Applied Microbiol. Biotechnol., 70: 679-682. DOI: $10.1007 / \mathrm{s} 00253-005-0138-\mathrm{z}$

Tan, T., M. Zhang, B. Wang, C. Ying and L. Deng, 2003. Screening of high lipase producing Candida sp. and production of lipase by fermentation. Process Biochem., 39: 459-465. DOI: 10.1016/S0032-9592(03)00091-8

Tan, T., J. Lu, K. Nie, L. Deng and F. Wang, 2010. Biodiesel production with immobilized lipase: A review. Biotechnol. Adv., 28: 628-634. DOI: 10.1016/j.biotechadv.2010.05.012

Thakur, S., 2012. Lipases, its sources, properties and applications: A review. Int. J. Sci. Eng. Res., 3: 1-29.

Treichel, H., D. de Oliveira, M.A. Mazutti, M. Di Luccio and J.V. Oliveira, 2010. A review on microbial lipases production. Food Bioprocess Technol., 3: 182-196. DOI: 10.1007/s11947-009-0202-2

Vakhlu, J. and A. Kour, 2006. Yeast lipases: Enzyme purification, biochemical properties and gene cloning. Electron. J. Biotechnol., 9: 69-85. DOI: 10.2225/vol9-issue 1-fulltext-9

Verger, R., 1997. "Interfacial activation" of lipases: Facts and artifacts. Trends Biotechnol., 15: 32-38. DOI: 10.1016/S0167-7799(96)10064-0

Wrostad, R.E., T.E. Acree, E.A. Decker, M.H. Penner and D.S. Reid et al., 2005. Handbook of Food Analytical Chemistry: Water, Proteins, Enzymes, Lipids and Carbohydrates. 1st Edn., pp: 624. 